\title{
Do common features exist among countries that locally adopt
}

\section{IFRS?}

\author{
Dr. Elizabeth Felski \\ SUNY Geneseo
}

Email: felski@geneseo.edu

DOI: 10.5296/ijafr.v5i2.8325 URL: http://dx.doi.org/10.5296/ ijafr.v5i2.8325

\begin{abstract}
Although International Financial Reporting Standards (IFRS) have clearly emerged as the preferred global accounting standard, previous studies of IFRS have mainly focused on post-adoption outcomes. The few IFRS adoption-focused studies are either limited in scope or are based on outdated versions of IFRS. This paper fills these holes in the literature by offering a comprehensive analysis of IFRS adoption: first, through an expanded classification system which includes local adoption as a distinct form of IFRS adoption and then through ANOVA, discriminant analyses and regression analyses. Several variables were identified as significant drivers of adoption status, one being the Asian region which consistently emerged as a powerful driver of adoption type suggesting previous analysis of IFRS diffusion is incomplete, missing this key region variable. This expanded typology suggests that the system of country classification of required/not required currently used is inadequate in capturing how IFRS is adopted in practice.
\end{abstract}

Keywords: IFRS, local adoption, comparability, international accounting

\section{Introduction}

The current era of globalization has broken down many previously constructed economic barriers. Foreign investors now have greater access to more globalized capital markets which increases their need for reliable and comparable financial information at the global level (Roussey, 1992; Wyatt \&Yospe, 1993; Lewis, 1996). Organizations such as the World Bank and the International Organization of Securities Commission (IOSCO) have endorsed International Financial Reporting Standards (IFRS) as the new guidebook for financial reporting harmonization. With over 130 countries currently requiring or permitting the use of IFRS, the harmonization process is well underway.

Yet, this harmonization is neither complete nor completely homogenous, with major economic partners such as the United States, India, and Japan resisting the full adoption of IFRS, and other countries adopting the standards in a piecemeal fashion. The hesitation of 
some countries to adopt IFRS rests in the questions of whether or not IFRS results in higher quality standards than their nation's existing standard, and whether they will in fact increase comparability. A common argument against IFRS implementation is that as compared to US standards, which have been refined over the years to represent a comprehensive set of rules and regulations, IFRS are principles-based which allows for flexibility. On the other hand, when compared to local standards from nations such as the United Kingdom or Australia, IFRS is argued to be too rule-based and not as flexible as previous local standards. It is argued that flexibility is necessary when adopting one set of standards on a global scale, yet others argue that this flexibility will result in less financial statement comparability, which is one of the major goals of IFRS implementation.

This raises, then, the question of motivations for adoption. Because worldwide adoption is still in its infancy, few studies have been conducted specifically on IFRS adoption at the country level. Traditional neo-classical economics points to economic growth as the incentive for regulatory harmonization, although Zaidi (2012) argues that current research studies do not provide conclusive evidence on the impact of IFRS adoption on countries' economic growth. My research extends previous research on IFRS adoption by identifying groups of countries that choose different IFRS adoption types. A country or region may choose to fully adopt IFRS, adopt it in a piecemeal fashion, allow IFRS for some companies, or not permit the use of IFRS. The purpose of my research is to examine what differentiates countries that choose different IFRS adoption types.

Overall, this research adds to our understanding of IFRS adoption by introducing a new typology of adoption types and identifying new drivers of different adoption types. My research uncovers variables that differ among adoption types, using these variables to create models designed to classify countries by adoption type. These models can help the accounting profession better understand what types of countries are choosing to either adopt, not adopt or locally adopt IFRS.

\section{Literature Review and Hypothesis Development}

\subsection{International Accounting Standards- Background}

Recently, the main focus of the accounting literature has been the adoption of an international set of accounting principles. Tarca (2012) argues that a single set of high quality global accounting principles has the potential to reduce the cost of financial preparation and improve the comparability and transparency of financial information. Additionally, IFRS proponents argue that one set of global accounting standards would lower the cost of capital, because capital market participants would have access to higher quality information which could lead to better decision making and more efficient market allocation of funds. Brown (2011) argues that higher quality global standards can improve the quality and comparability of financial information and promote the integration of markets internationally.

A country has several options when implementing IFRS. If a country chooses to fully adopt IFRS, all public companies are required to comply with IFRS as issued by the IASB. The convergence option allows the adopting country to maintain its standard-setting body and this body works with the IASB to develop new standards. If full adoption is not 
implemented, the country's standard-setting body retains control over the standards and can individually endorse, adjust or reject each standard allowing for local adoption (www.ifrs.com). This allows for a modified version of IFRS. Additionally, a country may choose to permit the use of IFRS as either issued by the IASB or a locally adopted version, or not permit the use of IFRS altogether. Because IFRS are principles-based it offers a variety of choices in many reporting areas which allows for soft adoption. Countries that use a less conservative approach to adoption take full advantage of the flexibility IFRS has to offer, leading to companies often making choices that make the company look better financially. For instance, Hellman (2011) found that in Sweden, companies often make choices that make earnings look better when compared with companies in countries that chose to implement a more conservative approach to adoption.

Convergence efforts are underway in countries like the US where the IASB and US regulatory bodies (FASB and SEC) are working together to converge their standards. The European Union (EU) required mandatory adoption of IFRS by all public companies in 2005 . The EU did not choose to implement IFRS as issued by the IASB but rather the endorsement method of adoption, essentially establishing locally adopted standards required for the entire EU. In a section entitled A Bewildering Variety of Methods of Implementation, Nobes (2011) outlines six different adoption methods employed by countries when choosing to implement IFRS.

1. Adopting the IFRS process, this is implementing IFRS in its purest form with no modifications.

2. Inserting IFRS unchanged in substance into law. This option results in a delay of implementation as each standard is endorsed by the countries' governing body one by one.

3. Endorsing IFRS allows for the governing body to examine each standard and selectively choose which to endorse.

4. Fully converging with IFRS allows the governing body to review each standard and make changes with the intent that, in time, the standards will lead to full compliance.

5. Adapting IFRS allows countries to use IFRS as a starting point, but the governing body makes considerable changes which results in several clear reporting differences.

6. Allowing IFRS is simply a country allowing the organization to decide if it chooses to follow IFRS or local GAAP.

This study clearly shows the complexity of options available to countries when deciding to implement IFRS. The current literature on IFRS adoption generally treats IFRS as a binary option; either IFRS is implemented or it is not. As Nobes (2011) shows, the process is much more complex resulting in many variations of IFRS use.

\subsection{IFRS Diffusion}

Few studies have been conducted on the diffusion of IFRS as it is a relatively recent process, with IFRS only emerging as the preferred global standards in the last 20 years. In their 2006 study, Zeghal and Mhedhbi set out to determine what factors affect a country's decision to adopt International Accounting Standards (IAS), IFRS' predecessor. The authors conclude that education level, the existence of financial markets, and cultural membership are 
factors that positively affect IAS adoption.

Another study uses a sample of 161 countries and institutional isomorphism theory to analyze why countries choose to adopt IFRS (Lasmin, 2011). Institutional isomorphism theory was developed by DiMaggio and Powell (1983) and provides an alternative framework for why standards are adopted. Their framework suggests that adoption provides legitimacy rather than actual performance improvement. The authors provide three forms of isomorphic changes from which their framework is derived; coercive isomorphism which entails political influence and legitimacy, mimetic isomorphism resulting from standard responses to uncertainty, and normative isomorphism which is associated with professionalization. Lasmin (2011) uses regression to test his hypothesis that IFRS diffusion is more related to socio-political pressures (coercive, mimetic and normative isomorphism) than it is to economic pressure. Average total foreign aid as a percent of GDP was used to represent the coercive factor, average market capitalization as a percentage of GDP to represent the mimetic factor and average enrolment of secondary schools as a percentage of total population to represent the normative factor. Economic factors were represented by average of FDI inflows as a percentage of GDP and average growth of GDP. The author concludes that although international organizations (e.g. IASB, the World Bank, IMF, United Nations, Organization for Economic Co-operation and Development (OECD), and the International Organization of Securities Commissions (IOSCO), promote IFRS as the preferred choice with the argument that it will bring economic growth, in fact social pressures were a better predictor than economic pressures when looking at IFRS adoption. Lasmin (2011) argues that the traditional neoclassical diffusion framework, which points to economic returns as primary reasons for standards adoption, has a heavy emphasis on investors and multi-national corporation interests which reflects Anglo-American accounting values and does not necessarily apply to all countries and contexts. Similarly, through a review of the literature, Chua and Taylor (2008) question the argument that the push for IFRS implementation is strictly economic and instead propose that social and political factors may also be an important driver. The authors argue that "the widespread diffusion today of IFRS can at best be only partially explained as an economically rational phenomenon. Rather, the demand for legitimate action in the face of tightly coupled and complex global markets is at least equally important in generating support for IFRS" (462). Similarly, Ramanna and Sletten (2014) argue that IFRS is influenced by perceived network benefits implying that countries could adopt IFRS even if local GAAP is of higher quality or better meets local reporting requirements.

Choi and Meek (2008) developed a framework, through a compilation of prior theoretical reasoning and empirical research, which identifies eight factors in a country's environment which are believed to have a significant influence on the differences found in accounting systems. Understanding what makes accounting systems different is an important step in understanding adoption choices. These eight factors include major sources of finance, legal systems, taxation, political and economic ties, inflation, economic development, education, and culture. Shima and Yang (2012) use the framework established by Choi and Meek (2008) to explain international accounting system development and to assess factors affecting a country's decision to adopt, not adopt or allow listed companies to 
use IFRS. The authors found that equity financing, taxation, and inflation were shown to have a negative relationship with IFRS adoption, while former colonization, IFRS adoption by top importer or exporter, foreign-sourced debt financing, economic growth rate, the gross capital formation, common law legal system, literacy rate and uncertainty avoidance were all shown to have a positive relationship to IFRS adoption. I also chose to start with the framework established by Choi and Meek because the categories established incorporate all of the variables found to be significant in the literature as a whole, as described in the preceding sections and below. Also, this framework is the only one of its kind that specifically looks at what drives accounting systems, pinpointing variables that differ between accounting systems. The following section is organized by the broad variables found to be significant by Choi and Meek, with discussion of specific measures drawn from the existing literature on both accounting standards and broader corporate governance standards diffusion.

\subsubsection{Major Funding Source}

It is suggested that countries that have well-developed stock markets generally have accounting standards that are considered more advanced than IFRS making them resistant to adoption (Ramanna and Sletten, 2014). The opposite is suggested to be true for countries primarily financed through debt. In these countries, accounting systems are generally designed around creditor protection which is thought to be communicated more efficiently through private channels reducing the need for public disclosures and transparent markets. Shima and Yang (2012) argue that this informal information sharing is much more difficult across borders, making IFRS adoption, and the accompanying transparency and disclosure, more beneficial for countries seeking foreign debt. I summarize these predictions in my first set of hypothesis:

H1: Countries' major source of finance impacts IFRS adoption.

H1a: Countries seeking external financing through FDI or aid are more likely to adopt IFRS.

H1b: Countries seeking financing through equity are less likely to adopt IFRS.

\subsubsection{Legal Systems and Taxation}

Daske et al. (2008) suggests that IFRS adoption may only lead to benefits for those countries where there is greater incentive for better disclosure. Because legal systems have been directly associated with disclosure practices (Doupnik\& Salter, 1995; Jaggi\& Low, 2000) and variations in reporting incentives (Ball et al., 2000), it stands to reason that a country's legal system may impact its financial reporting decision making. Research has identified two major legal systems, code law and common law. Shima and Yang (2012) argue that because code law countries adhere to the stakeholder model where communication is conducted mainly through private networks, they are less likely to adopt IFRS than common law countries, which adhere to a shareholder model in which information asymmetry is thought to be resolved through public disclosure and transparency.

A country in which government has greater control over managing its resources (through state ownership in listed companies) tends to have higher government involvement 
in the development of reporting standards (Alnajjar, 1986; Doupnik\& Salter, 1993; Xiao et al., 2004). When governments are highly involved in the development of reporting standards, the main focus of these standards tends to be regulatory, focused mainly on taxation and compliance. Because the main focus of IFRS is transparency and disclosure, Shima and Yang (2012) suggest that countries with central governments that depend heavily on tax revenue for funding are less likely to adopt IFRS. This logic leads to my second set of hypotheses:

H2: Countries' legal and taxation systems impact IFRS adoption.

H2a: Code law countries are less likely to adopt IFRS.

H2b: Countries more heavily dependent on tax revenue are less likely to adopt IFRS.

\subsubsection{Political and Economic Ties}

Shima and Yang (2012) argue that because IFRS is primarily influenced by UK GAAP, countries that have been previously colonized by the UK have a higher likelihood of adopting IFRS. Along with their accounting system, many countries outside Europe have also inherited their former colonizer's legal system. Colonization history was excluded because although Nobes (1998) argues that many countries outside Europe have inherited their accounting system from their former colonizer, the same can be said for their legal system therefore including both legal system and colonization history is not necessary.

Trade agreements among countries have been linked to reporting standards harmonization even when the contracting partners are socially, politically, and culturally diverse (Craig \&Diga, 1996; Saudagaran \& Diga, 2000). This is thought to occur because harmonization of standards can minimize differences between members making trade flow easier. Easier trade flows may cause countries that have already adopted IFRS to pressure their trading partners to also adopt IFRS, or countries that do not currently use IFRS may adopt these standards in hopes of increasing trade with an already established trading partner. In this vein, Neumayer and Perkins (2005) found a country's level of exports to the European Union (EU) to be a significant factor in ISO certification. Exports to the EU proved to be a challenging variable. Including dollar amount of exports would not be appropriate as it does not take into account size of exporting countries' economy. As an alternative measure, I then constructed a dummy variable that indicated whether or not the EU was one of the adopting countries top five exporters. In almost all cases this was true making this variable not very useful, I therefore excluded it.

\subsubsection{Inflation and Economic Development}

Choi and Meek (2008) argue that in regions with high or hyper-inflationary economies, inflation is an accepted part of doing business and these economies have adapted by creating more complex reporting rules and regulations. Investopedia defines inflation as the rising of the cost of goods and services causing the purchasing power to decrease. Hyper-inflation occurs when there is a large increase in money supply that is not supported by an increase in GDP therefore causing an imbalance of supply and demand of currency. Doupnik \& Salter (1995) argue a country with high inflation may have adapted its reporting requirements by requiring the preparation of multiple financial statements using different 
reporting requirements, whereas IFRS requires the preparation of only one set of statements that could be perceived as misleading. Shima and Yang (2012) argue that although IAS 29 requires a restatement of non-monetary items based on a change in the general price level index at the balance sheet date this may not allow "sufficiently suitable alternative reporting methods as compared to local GAAP" (281).

Several studies have been conducted exploring the links between economic development and increased disclosure. The theory behind a positive linkage is that as economies develop, the business transactions occurring are increasing in number and complexity and a more complex and sophisticated recording and reporting process is needed to accurately capture these transactions. Some research does point to a positive linkage between economic development and increased disclosure when proper enforcement is present (Cooke \& Wallace, 1990; Belkaoui, 1995; Salter, 1998). Other studies have found no significant relationship between economic development and increased disclosure (Adhikari\&Tondkar, 1992), or even a negative relationship (Larson \& Kenny, 1995). I summarize these findings into the following hypotheses:

H3: Countries' rate of inflation and level of economic development impacts IFRS adoption.

H3a: Countries with high inflation are less likely to adopt IFRS.

H3b: Countries that are less developed are less likely to adopt IFRS.

\subsubsection{Education and Culture}

Shima and Yang (2012) argue that a more highly educated population will need a more sophisticated accounting system to meet its information needs, and in turn a highly educated population is needed to interpret and apply the more sophisticated standards.

Geiger and van der Lann Smith (2010) argue that accounting, because it is a socio-technical activity that involves humans, cannot be culture-free and that culture has been found to influence the development of accounting systems, the perception of the participants, and the application of financial reporting rules within accounting systems. Hofstede's cultural dimensions have been commonly accepted in the business world as measures of cultural values. These cultural dimensions were later linked to accounting values by Gray (1988), and then empirically tested by Salter and Niswander (1989). Braun and Rodriguez (2008, 3-4) described Hofstede's cultural dimensions as well Gray's accounting values as follows:

Power Distance- the extent to which the less powerful members of institutions and organizations within a country expect and accept that power is distributed unequally.

Uncertainty Avoidance- the extent to which members of a culture feel threatened by uncertain or unknown situations.

Individualism- refers to society wherein ties between members are relatively loose, whereas Collectivism refers to a society in which members are integrated into a cohesive group.

Masculinity- refers to a society in which gender roles are distinct with men expected to be tough and assertive, whereas Femininity refers to a society where gender roles overlap and both sexes are expected to display modesty and a concern for quality of life. 


\section{Ml Macrothink}

International Journal of Accounting and Financial Reporting

ISSN 2162-3082

2015, Vol. 5, No. 2

Professionalism versus Statutory Control- a preference for the exercise of individual professional judgment and the maintenance of professional self-regulation as opposed to compliance with prescriptive legal requirements and statutory control. A country that places a high value of professionalism will have a higher individualism score and lower uncertainty avoidance and power distance scores.

Uniformity versus Flexibility- a preference for the enforcement of uniform accounting practices between companies and for the consistent use of such practices over time as opposed to flexibility in accordance with the perceived circumstances of individual companies. A country that places a high value on uniformity will have higher uncertainty avoidance and power distance scores and a lower individualism score.

Conservatism versus Optimism- a preference for a cautious approach to measurement so as to cope with the uncertainty of future events as opposed to a more optimistic, laissez-faire, risk-taking approach. A country that places a high value on conservatism will have a higher uncertainty avoidance score and lower individualism and masculinity scores.

Secrecy versus Transparency- a preference for confidentiality and the restriction of disclosure of information about the business only to those that are closely involved with its management and financing as opposed to a more transparent, open and publicly accountable approach. A country that places a high value on secrecy will have higher uncertainty avoidance and power distance scores and lower individualism and masculinity scores.

Salter and Niswander (1995) found a significant relationship between Gray's accounting values and Hofstede's cultural dimensions. The results suggest countries with low levels of uncertainty avoidance were less likely to have accounting systems driven by rigid accounting rules versus disclosure driven by marketplace demands. Shima and Yang (2012) suggest that countries with high uncertainty avoidance are less likely to adopt IFRS. The authors argue this is because countries with high uncertainty avoidance prefer accounting systems that are more secretive and IFRS claims to produce more transparent financial statements.

Braun and Rodriguez (2008) use Gray's framework to test for the relationship between these cultural characteristics and earnings management. The results indicated that high statutory control, high uniformity, high conservatism, and high secrecy all lead to earnings management. Earnings management is thought to decrease under IFRS, therefore countries' heavily reliant upon earnings management techniques would be less likely to adopt IFRS. Later, long-term vs short term orientation was added to Hofstede's cultural dimensions. This led to the formation of my fourth set of hypotheses:

H4: Countries' education and cultural impacts IFRS adoption.

H4a: Countries with higher levels of education are more likely to adopt IFRS.

H4b: Countries with high uncertainty avoidance are less likely to adopt IFRS.

H4c: Countries that have a higher level of statutory control are less likely to adopt IFRS. 
H4d: Countries that have higher uniformity are less likely to adopt IFRS.

H4e: Countries that have higher conservatism are less likely to adopt IFRS.

H4f: Countries that have higher secrecy are less likely to adopt IFRS.

H4g: Countries that are more long-term oriented are less likely to adopt IFRS.

\subsubsection{Other}

Lasmin (2012) argues that geographic region is a variable that needs to be controlled for when looking at IFRS adoption. This is because countries within close proximity tend share more information and trade and therefore may also be more likely to adopt the same IFRS status. The World Bank offers geographic country groupings used by Lasmin (2012).

\section{Empirical Design}

In order to test these hypotheses I started with the IASPlus website, classifying all listed countries in one of four categories: not-permitted, permitted, locally adopted, or required, see Table 1 (for the discriminant and regression analysis the not-permitted and permitted categories were combined to form a not required category). My research is focused on current reporting requirements and how IFRS adoption actually differs in substance. This being said, my typology combines Nobes categories 1 and 2, as the end result is not different, to create an IFRS as issued by the IASB category. Categories 3, 4 and 5 were also combined to form a locally adopted category, which encompasses all countries that make modification to IFRS. I further isolated the

Table 1 - Adoption Status by Country

\begin{tabular}{|c|c|c|c|c|}
\hline \multicolumn{2}{|c|}{ Required IASB } & Locally Adopted & Not Required* & Required EU \\
\hline Canada & Botswana & El Salvador & Bermuda & Austria \\
\hline Mexico & Ghana & Uruguay & United States & Belgium \\
\hline Anguilla & Kenya & Bosnia and Herzegovina & Argentina & Bulgaria \\
\hline Antigua and Barbuda & Malawi & Macedonia, FYR & Bolivia & Croatia \\
\hline Bahamas, The & Mauritius & Serbia & British Virgin Islands & Cyprus \\
\hline Barbados & Morocco & Azerbaijan & Cayman Islands & Czech Republic \\
\hline Brazil & Namibia & Georgia & Colombia & Denmark \\
\hline Chile & Nigeria & Moldova & Cuba & Estonia \\
\hline Costa Rica & Rwanda & Mozambique & Haiti & Finland \\
\hline Dominica & Sierra Leone & Australia & Paraguay & France \\
\hline Dominican Republic & South Africa & Bangladesh & Suriname & Germany \\
\hline Ecuador & Swaziland & Hong Kong SAR, China & Gibraltar & Greece \\
\hline Grenada & Tanzania & Japan & Isle of Man & Hungary \\
\hline Guatemala & Uganda & Nepal & Switzerland & Iceland \\
\hline Guyana & Zambia & New Zealand & Turkmenistan & Ireland \\
\hline Honduras & Bahrain & Pakistan & Benin & Italy \\
\hline Jamaica & Iraq & Philippines & Burkina Faso & Latvia \\
\hline Netherlands Antilles & Israel & Singapore & Cote d'Ivoire & Liechtenstein \\
\hline Nicaragua & Jordan & Taiwan & Egypt, Arab Rep. & Lithuania \\
\hline
\end{tabular}




\begin{tabular}{|c|c|c|c|c|}
\hline Panama & Kuwait & Thailand & Lesotho & Luxembourg \\
\hline Peru & Lebanon & & Mali & Malta \\
\hline St. Kitts and Nevis & Oman & & Niger & Netherlands \\
\hline St. Lucia & Qatar & & Senegal & Norway \\
\hline Trinidad and Tobago & Saudi Arabia & & Togo & Poland \\
\hline Venezuela, RB & United Arab Emirates & & Tunisia & Portugal \\
\hline Montenegro & West Bank and Gaza & & Zimbabwe & Romania \\
\hline Armenia & Cambodia & & Iran, Islamic Rep. & Slovak Republic \\
\hline Belarus & Fiji & & Bhutan & Slovenia \\
\hline Kazakhstan & Korea, Rep. & & China & Spain \\
\hline Kyrgyz Republic & Malaysia & & India & Sweden \\
\hline Russian Federation & Mongolia & & Indonesia & Turkey \\
\hline Tajikistan & Vietnam & & Lao PDR & $\begin{array}{l}\text { United } \\
\text { Kingdom }\end{array}$ \\
\hline Ukraine & Libya & & Maldives & \\
\hline \multirow[t]{2}{*}{ Uzbekistan } & Papua New Guinea & & Myanmar & \\
\hline & Sri Lanka & & & \\
\hline
\end{tabular}

Adoption status by country

EU into its own category, IFRS as implemented by the EU. This is an important distinction because all EU countries were required to implement the same version of IFRS at the same time, in 2005. Because my research focuses on why countries adopt IFRS, it is important to isolate these countries as a separate group as they did not independently choose their implementation method. I have also included a category for countries that permit the use of IFRS and those that do not allow IFRS.

The IAS Plus website is a database of information collected by Deloitte ToucheTohmatsue Limited, the largest public accounting firm in the world. Countries that allow companies to voluntarily adopt IFRS are considered permitted. Countries that adopt IFRS but made any type of modification at the country level are considered locally adopted. My research focused on the countries' mandate for publicly-traded companies; therefore, if modifications or exceptions were made mainly for private companies but publicly-traded ones were required to follow IFRS, the countries were classified as required. One such example is Canada where IFRS is not required for pension plans, deposit taking entities, rate regulating entities, and insurance companies.

Countries that developed a modified version of IFRS that it permits some firms to use, like Japan, are classified as locally adopted. Countries that require the use of an outdated version of IFRS, such as El Salvador which uses a 2003 version, are considered local adopters. This is important because many since January 2011 alone, over 70 pronouncements have been issued that either modify an existing standard or create a new standard. Countries relying on an outdated version of IFRS do not enforce recent changes therefore creating a modified version of IFRS as issued by the IASB. Countries such as China, where local GAAP has substantially converged with IFRS, are classified as not required because translation errors and discrepancies are common and can results in reporting differences. Because I 
focused on public companies, data was collected from those countries that have a local stock exchange. Any country that mandates public companies to follow IFRS as issued by the EU is considered required as endorsed by the EU. As my research is focused on country level data that may affect a countries' decision to adopt IFRS, it is important to isolate the EU as a separate adoption category because all of the EU countries were required to adopt IFRS in 2005 regardless of their individual country situation.

Adoption status information was available for over 150 countries with data mainly missing from African countries. After collecting data from the IASPlus website, I then cross-checked all of the information with Price water house Coopers, LLP publication, IFRS Adoption by Country which is available through their website. PricewaterhouseCoopers, LLP is the world's second largest public accounting firm.

As discussed previously, prior studies of IFRS adoption patterns and economic growth impacts have generally treated adoption status as a binary value, either adoption or non-adoption. Countries that permitted, but did not require, IFRS were treated as non-adopters. I find this problematic because IFRS may in fact be used extensively in these countries, but because they are not required to do this by an authoritative body, they are classified in the same category as a country that does not allow IFRS. For example, Switzerland permits the use of either IFRS or US GAAP (for locally listed companies) although a study of 238 companies listed on the Swiss exchange in January 2015 shows $91 \%$ of the companies seeking international investors use IFRS and overall $63 \%$ of the sampled countries reported using IFRS (www.ifrs.org).

In order to test my hypotheses, I first performed an ANOVA (Analysis of Variance), which is designed to test the assumption that there is no difference in means between various groups. A separate ANOVA analysis was conducted for each independent variable. In addition to conducting an ANOVA analysis on the expanded groupings, on the same independent variables I conducted an ANOVA analysis using the traditional classification of adoption vs. non-adoption to see if additional variances are found when further breaking down the categories. Also, because all EU countries were mandated to adopt IFRS as issued by the EU in 2005, I ran a separate ANOVA analysis where I treated all EU countries as one observation. I obtained financial data on the EU as a whole from the World Development Index and averaged all of the cultural variables. There are four countries, Turkey, Lichtenstein, Iceland and Norway, which require the use of IFRS as issued by the EU but are not part of the EU and are therefore not included in the EU data provided. These three countries were categorized as locally adopted for this ANOVA test.

For all financial data I used the most current year's numbers that were available. I chose to use only the current year instead of a multi-year average because many countries adopted IFRS in the most current year data was available, in most cases 2012 or 2013. Overall, the study is more relevant and robust with the inclusion of these newly adopted countries. Although I realize IFRS adoption is a moving target, comparing variables spanning 40 years would not be comparable. For example, if I used 3 year pre-adoption averages of inflation I would be comparing data from the 1970 to 2014 without controlling for other factors that may impact inflation. Tax rates were obtained from $\mathrm{PwC}$ and were updated May 15, 2014. This would reflect the tax rates for the 2013 tax year. To double-check the rates and 
to fill in missing data, I used Deloitte's International Tax Highlight by Country guide and the International Finance Corporation's Paying Taxes in 2014: The Global Picture. Because a separate ANOVA was conducted on each independent variable the sample size varied depending on data availability.

ANOVA assumes that the residuals of the independent variables are normally distributed, that the observations between and within samples are random and independent, and that the population variances are equal for each category. Using Minitab, I conducted both a test for equal variances and a residuals normality test for each independent variable. Rogerson (2010) notes that ANOVA is quite robust in terms of both the normality and equal variance assumptions and that relying on a smaller P-Value for variables found to violate any of these assumptions is sufficient if the P-Value is not close to the accepted level of significance. Rogerson (2010) also suggests one possible alternative test that makes no assumption about distribution is the Kruskal-Wallis test. For all variables that were found to violate either assumption, a Kruskal-Wallis test was conducted to confirm the ANOVA results.

To gain a better understanding of what differentiates countries with different adoption types, and to validate my ANOVA results, I conducted both a linear discriminant analysis and a multinomial regression analysis. Linear discriminant analysis is used to determine which variables discriminate between two or more classes resulting in a classification model of group membership of an observation (Pohar et al, 2004). In this research, I used linear discriminant analysis to create a model, using the variables shown in table 2, to classify countries into the following groups: required IASB, required EU, not required, or locally adopted.

Table 2 - Variables Used

\begin{tabular}{|l|l|l|l|l|}
\hline \multicolumn{1}{|c|}{ Variable } & \multicolumn{1}{|c|}{ Description } & \multicolumn{1}{c|}{ Source } & Variable Type \\
\hline Adoption status & $\begin{array}{l}\text { Required by IASB Locally } \begin{array}{r}\text { Required by } \\
\text { Adopted } \\
\text { EU Permitted } \\
\text { Permitted }\end{array} \\
\text { Major Source of Finance }\end{array}$ & Dependent \\
\hline $\begin{array}{l}\text { Foreign Direct } \\
\text { Investment }\end{array}$ & $\begin{array}{l}\text { Measures Inflows of Foreign Direct } \\
\text { Investment as a percentage of GDP; log }\end{array}$ & WDI- 2013 & Independent \\
\hline Debt & $\begin{array}{l}\text { Measures total external debt stocks, log } \\
\text { Aid }\end{array}$ & $\begin{array}{l}\text { Net official development assistance and } \\
\text { official aid received; log }\end{array}$ & WDI-2013 & Independent \\
\hline Publicly Traded & $\begin{array}{l}\text { Bank or market oriented- number of publicly } \\
\text { traded firms per 100 people-proxy for the } \\
\text { degree to which a country's financial system } \\
\text { is market oriented }\end{array}$ & $\begin{array}{l}\text { World Bank } \\
\text { Development and Structure } \\
\text { dataset- April 2013 }\end{array}$ & Financial & Independent \\
\hline $\begin{array}{l}\text { Market } \\
\text { Capitalization } \\
\text { Percentage }\end{array}$ & $\begin{array}{l}\text { Measures the financial liquidity of a country, } \\
\text { as a percent of GDP }\end{array}$ & WDI- 2013 & \\
\hline Legal System and Taxation & & \\
\hline
\end{tabular}




\begin{tabular}{|c|c|c|c|}
\hline Legal System & Code or Common Law & $\begin{array}{l}\text { World Factbook, } \\
1=\text { Common Law } \\
0=\text { Other }\end{array}$ & $\begin{array}{l}\text { Independent- } \\
\text { Dummy }\end{array}$ \\
\hline Taxation & $\begin{array}{l}\text { Measured as the highest marginal corporate } \\
\text { tax rate }\end{array}$ & $\begin{array}{l}\text { PwC Corporate Tax Worldwide } \\
\text { Summary }\end{array}$ & Independent \\
\hline \multicolumn{4}{|c|}{ Inflation and Economic Development } \\
\hline Inflation & Inflation rate & WDI- 2013 & Independent \\
\hline $\begin{array}{l}\text { Level of } \\
\text { Development }\end{array}$ & Based on GNI per capita & $\begin{array}{l}\text { World Development } \\
\text { Indicators- } 2013 \\
\text { Issued by the World Bank }\end{array}$ & Control \\
\hline \multicolumn{4}{|c|}{ Education and Culture } \\
\hline $\begin{array}{l}\text { Level of } \\
\text { Education }\end{array}$ & Measures literacy rate of a given country & $\begin{array}{l}\text { Percentage of primary school } \\
\text { enrollment taken from WDI } \\
\text { and ranges from } 0 \text { to } 100 \\
\text { where higher values indicate } \\
\text { higher education level. }\end{array}$ & Independent \\
\hline $\begin{array}{l}\text { Uncertainty } \\
\text { Avoidance }\end{array}$ & Hofstede's Cultural Dimension & $\begin{array}{l}\text { Country level numerical score, } \\
\text { Hofstede, } 2001\end{array}$ & Independent \\
\hline $\begin{array}{l}\text { Gray's } \\
\text { Accounting } \\
\text { Values }\end{array}$ & $\begin{array}{l}\text { Professionalism v. Statutory Control, } \\
\text { Uniformity v. Flexibility, Conservatism v. } \\
\text { Optimism and Secrecy v. Transparency }\end{array}$ & $\begin{array}{l}\text { County level score, Braun and } \\
\text { Rodriguez, } 2008\end{array}$ & Independent \\
\hline $\begin{array}{l}\text { Long term v. } \\
\text { Short term }\end{array}$ & Hofstede cultural dimension & $\begin{array}{l}\text { Country level numerical score, } \\
\text { Hofstede, } 2010\end{array}$ & Independent \\
\hline \multicolumn{4}{|l|}{ Other } \\
\hline Region & $\begin{array}{l}\text { WTO regions, } 1-7 \quad 7 \text { variables total- } 1 \text { for } \\
\text { each region coded } 1 \text { if yes } 0 \text { if no }\end{array}$ & WTO & Independent \\
\hline
\end{tabular}

Summary of variable used

Linear discriminant analysis does make the assumption that the independent variables are normally distributed. In this case many of the variables have non-normal distributions. Pohar et al (2004) notes that in cases where independent variables are not normally distributed, logistic regression may be a better fit, although they found negligible differences in results between linear discriminant analysis and logistic regression when sample sizes were greater than 50. In addition, the authors found that when more categories are needed (more than 2 or 3 ) for the dependent variable, linear discriminant analysis is usually a better fit. Because of the assumption violation, I conducted a logistic regression, which makes no distribution assumptions, as well as the discriminant analysis to confirm my findings.

The goal of logistic regression is to find the best fitting and most parsimonious model to describe the relationship between the dependent variables and the independent variables (Pohar et al, 2004). Because my dependent variable is categorical I cannot use linear regression. One way to overcome this is to take the logistic transformation of the data and make that linear. This model uses the log of the odds (logits) as an observation falls into a specific category to form predictions. The model will result in $\mathrm{k}-1$, in this case three, logits 
comparing each group to the reference group. According to Hardy (1993) the reference group should be well defined and a category that is heavily populated; I therefore chose Required IASB as the reference group. Because my data is nominal and I have multiple categories for the dependent variable, I must use multinomial logistic regression. In order to create a model, I started with the variables that were found to be significant in both ANOVA and the discriminant analysis, again eliminating those that were highly correlated. One by one variables that were found to be insignificant ( $\mathrm{P}$-value of greater than .05 ) were eliminated from the model until only significant variables remained. In addition, I added the variables that were not found to be significant in my ANOVA analysis and my discriminant analysis to make sure they were not found to be significant in this analysis. Table 3 summarizes the variables used in this study as well as their source.

\section{Results and Discussion}

\subsection{ANOVA}

Table 3 summarizes the p-values resulting from my ANOVA analysis. All variables identified in the literature as significant, as well as my additions of region and long-term $\mathrm{V}$ short term orientation was tested. Because ANOVA only tells us that at least one mean is different from at least one other, a Fisher Pair wise Comparison was conducted on all variables found to be significant in the four and five category models to determine which category has a different mean. The results of this comparison can be found in table 4 .

Some of the variation in my analysis can be explained by the general EU effect, meaning many EU countries have common characteristics, which would differ from other countries around the world. For example, my analysis shows the EU countries have lower debt and foreign aid and a higher level of development than countries in other regions. These common characteristics did not cause the EU countries to adopt a certain form of IFRS, rather the mandate from the EU did. For this reason, I preformed ANOVA using the entire EU as a variable in the locally adopted category instead of treating Required EU as a separate category. The five category model includes IFRS as issued by the IASB, permitted, not permitted, required EU and locally adopted. The four category model includes the EU as an observation in locally adopted category.

Table 3

\begin{tabular}{|c|c|c|c|}
\hline \multirow[b]{3}{*}{ Independent Variable } & \multicolumn{2}{|c|}{ P-value } & \multirow{3}{*}{$\begin{array}{c}\text { Four } \\
\text { Categories }\end{array}$} \\
\hline & Two & Five & \\
\hline & Categories & Categories & \\
\hline Taxation & 0.812 & $0.002 *$ & $0.003 *$ \\
\hline Development & 0.420 & $0.000 *$ & $0.049 \sim$ \\
\hline Professionalism & 0.893 & $0.004 *$ & 0.287 \\
\hline Uniformity & 0.899 & $0.004 *$ & 0.272 \\
\hline Conservatism & 0.206 & 0.127 & 0.209 \\
\hline Secrecy & 0.436 & $0.011 *$ & 0.134 \\
\hline Long Term & 0.207 & $0.027 *$ & 0.415 \\
\hline Legal System & 0.380 & $0.015^{*}$ & 0.069 \\
\hline
\end{tabular}




\begin{tabular}{|l|c|c|c|}
\hline Debt & 0.082 & $0.000^{*}$ & 0.107 \\
\hline Aid & 0.051 & $0.000^{*}$ & 0.077 \\
\hline Education & 0.587 & 0.200 & 0.285 \\
\hline Publicly Traded & 0.064 & 0.065 & 0.126 \\
\hline Inflation & 0.665 & 0.087 & 0.527 \\
\hline Market Cap \% & 0.992 & 0.517 & 0.615 \\
\hline Uncertainty & 0.770 & 0.308 & 0.149 \\
\hline FDI and Central & 0.120 & 0.651 & 0.330 \\
\hline North America & 0.186 & 0.584 & 0.685 \\
\hline $\begin{array}{l}\text { South and } \\
\text { America and }\end{array}$ & 0.542 & $0.000^{*}$ & \\
\hline Caribbean & $0.010^{*}$ & $0.000^{*}$ & $0.000^{*}$ \\
\hline $\begin{array}{l}\text { Europe } \\
\text { Independent States }\end{array}$ & 0.222 & 0.134 & 0.429 \\
\hline Africa & $0.019^{*}$ & $0.000^{*}$ & $0.003^{*}$ \\
\hline Middle East & 0.222 & $0.014^{*}$ & $0.048^{*}$ \\
\hline Asia & 0.277 & $0.000^{*}$ & $0.011^{*}$ \\
\hline
\end{tabular}

ANOVA- P Value Summary

*Variables found to be significant at $95 \%$ level of confidence.

$\sim$ Kruskal-Wallis failed to find a difference in mean

Four cultural attributes were found to be significant in the five categories ANOVA mainly due to the Required EU category. The analysis shows that EU countries rely more significantly on professional control and allow more accounting policy flexibility and transparency than the countries that require IFRS as issued by the IASB. When compared to the countries that require IFRS as issued by the IASB and the countries that permit the use of IFRS the required EU countries are more long-termed focused. I believe these cultural differences are due to the general EU effect as they are not found to be significant in the four category ANOVA.

Legal system was also found to be significantly different for the required EU countries when compared to countries permitted to use IFRS and those required to use IFRS as issued by the IASB. This indicates that the EU countries are less likely to have a common law form of Governance. Countries that permit the use of IFRS are more likely to have a common law form of governance than those that do not permit the use of IFRS. Additionally, external debt and aid were found to be significantly lower for the required EU countries than all other categories. When I preformed ANOVA with the EU as one case, not surprisingly, these variables were no longer found to have significantly different means. These differences are most likely due to the EU effect and were therefore no longer found significant when the EU was treated as one case in the locally adopted category.

On the other hand, taxation and level of development were found to be significant in both the four and five category ANOVAs. For taxation, the Fisher Pairwise comparison indicates the permitted category is significantly lower than the not permitted and required 
IASB adoption categories. These results are consistent with Shima and Yang's (2012) argument that countries with high income tax rates are less likely to adopt IFRS. One argument for this is that countries heavily dependent on tax revenue are less likely to rely on accounting policy not designed for tax purposes.

A common argument suggested is that as countries develop their accounting transactions become more complex and therefore demand a more complex reporting process (Cooke \&Wallace (1990), Belkaoui (1995), Salter (1998)). An argument can thus be made that countries that are less developed are less likely to adopt IFRS. This argument seems to be validated by my ANOVA results. The lowest level of development is found in the not permitted category. The required EU, permitted IASB and locally adopted categories has the highest level of development. This can be explained by the fact that the most developed countries are in Europe, have the resources to implement their own modified version of IFRS or have a similarly sophisticated reporting process already in place. Although the development variable was found significant in the four category ANOVA test, it was not found to be significant in the subsequent Kruskal-Wallis test (see appendix 1). This indicates there is not a significant difference in means when the European Union is added as a variable to the locally adopted category suggesting much of the difference indicated by the ANVOA was due to the high level of development in Europe.

In terms of regional differences, no significant differences were found in North America and the Commonwealth of Independent States (Russia and former Russian states). One reason why no differences were found could be due to the small sample sizes in these regions, 4 and 12 respectively. The Fisher Pairwise comparison indicates countries classified as South and Central America and the Caribbean are most likely to choose permitted and required IASB as their IFRS adoption method. Europeis not surprising dominated by either the required EU or locally adopted category. This is mainly due to the EU mandate. In Africa, and the Fisher Pairwise comparison analysis shows that the not permitted category has a mean of .5, indicating that half of all the countries with data available in this region do not permit the use of IFRS. These results were consistent with a study conducted by Mande (2014), which looked at IFRS adoption in Nigeria. The author argues that within the African region the regulatory process lacks the required strategies to promote compliance with IFRS. Additionally, constraints such as low budgets, an inactive monitoring and collection process for the required information, a multiplicity of conflicting rules and impunity for the regulatory agencies to enforce rules make the process, if attempted, difficult. The Middle East is dominated by the required IASB adoption method.

The Asian region's Fisher Pairwise comparison shows us that over 50\% (.550) of the countries in this region locally adopt IFRS to meet their individual countries' reporting needs with less than $12 \%$ of countries choosing to implement IFRS as issued by IASB. Although initially surprising, one explanation for these results may be that many of the countries in this region rely on business practices that are heavily dependent on locally embedded relationships which include relationships with other large family-run businesses, banks and governments which causes local dependence. This local dependence could explain why this region, despite recent high economic growth, has not seen the level of global convergence as other regions have. This is consistent with Amable's (2003) argument that Asia has its own 
distinct form of capitalism which is summarized as follows:

[t]he main features of the Asian model can be said to be the following (ibid.): a close relationship between the government and businessgovernment's interventions are made after consultation with business, and such interventions are carried out through a system of 'administrative guidance' rather than through formal legislation; a specific financial system, with long-term relationships between banks and firms; cooperative relationships between management and labour in the internal pattern of Firms' organization in connection with supporting labour-market 'imperfections'; a reluctance to consider perfect competition on product markets as more efficient than 'guided competition'; and a strategic pattern of integration within the world economy, leaving finance and science sectors isolated from external competitive pressure (pg. 84).

The Organization for Economic Co-operation and Development (OECD) and the World Bank organized a roundtable discussion on corporate governance where Rahman (2000) presented a paper entitled Accounting Standards in East Asia Region. The author argues that although East Asian countries have local guidelines established that are modeled after IAS, in practice, the financial statements prepared by these countries rarely comply fully with these standards. Rahman goes on to state the problem mainly exists due to inadequate enforcement mechanisms. This suggests that even if these countries claim to be using IFRS, or a modified form of IFRS, in reality the statements may not reflect these standards.

\subsection{Linear Discriminate Analysis}

In an effort to validate my ANOVA results, I conducted three separate discriminant analyses; one using the categories required/not required, one using required EU as a category and one using the EU as one case in the locally adopted category. For this analysis I combined the categories not permitted and permitted to form the not required category. I did so because the permitted group had only a few observations for which I had access to all of the data needed. The final sample size is 64 total; 10 locally adopted, 9 not required, 18 required EU and 27 required IASB. Although some researchers suggest a sample size of at least ten events per predictor variable, Vittinghoff and McCulloch (2007) argue that in many cases a sample size of at least five per independent variable is sufficient although caution should be exercised. Starting with my ANOVA significant variables, I then eliminated some variables due to high correlation (correlation greater than 0.7 ) with other independent variables. Level of professionalism is highly correlated with level of uniformity, level of conservatism, and level of secrecy. Also, level of uniformity was correlated with level of conservatism, and level of secrecy. In addition, total external debt and aid were found to be highly correlated. For both the discriminant analysis and logistic regression I limited the region variables to just the Asian region to avoid potential problems with multicollinearity and quasi-separation or full separation of the data. Data separation is common when the explanatory variable is a dummy variable and for one value of $\mathrm{x}$, every case has an event of 1 
or 0 (Allison, 2008). I chose the Asian region due to its high level of local adoption shown in the ANOVA. This left the variables taxation, legal system, professionalism v. statutory, Asia, long term, level of development and total external debt. In addition to these variables I conducted a backwards analysis to check for any other variables that may contribute to my analysis. Backwards analysis consists of adding all of variables into the model eliminating, one at a time, the least significant variable until only the variables that significantly contribute to the discrimination between groups are left. The results are shown in tables $5-7$. Level of development was included in the models as a control variable.

Table 5 - Minitab Results Linear Discriminant Analysis- Four Categories

\begin{tabular}{|c|c|c|c|c|}
\hline \multirow[b]{2}{*}{ Put into Group } & \multicolumn{4}{|c|}{ True Group } \\
\hline & $\begin{array}{l}\text { Locally } \\
\text { Adopted }\end{array}$ & Not Required & $\begin{array}{l}\text { Required } \\
\text { EU }\end{array}$ & $\begin{array}{l}\text { Required } \\
\text { IASB }\end{array}$ \\
\hline Locally Adopted & 9 & 2 & 0 & 2 \\
\hline Not Required & 0 & 1 & 0 & 0 \\
\hline Required EU & 0 & 2 & 16 & 2 \\
\hline Required IASB & 1 & 2 & 1 & 21 \\
\hline Total N & 10 & 7 & 18 & 25 \\
\hline $\mathrm{N}$ correct & 9 & 1 & 16 & 21 \\
\hline Proportion & .900 & .143 & .889 & .840 \\
\hline $\mathrm{N}=60$ & & Proportion C & orrect $=0.783$ & \\
\hline \multicolumn{5}{|c|}{ Squared Distance Between Groups } \\
\hline & $\begin{array}{l}\text { Locally } \\
\text { Adopted }\end{array}$ & Not Required & $\begin{array}{l}\text { Required } \\
\text { EU }\end{array}$ & $\begin{array}{l}\text { Required } \\
\text { IASB }\end{array}$ \\
\hline Locally Adopted & 0 & 4.1584 & 10.9207 & 11.4088 \\
\hline Not Required & 4.1584 & 0 & 3.4195 & 4.0860 \\
\hline Required EU & 10.9207 & 3.1495 & 0 & 5.1552 \\
\hline Required IASB & 11.4088 & 4.0860 & 5.1552 & 0 \\
\hline
\end{tabular}

Linear Discriminant Function for Groups

\begin{tabular}{|l|r|r|r|r|}
\hline & \multicolumn{1}{l|}{$\begin{array}{l}\text { Locally } \\
\text { Adopted }\end{array}$} & Not Required & \multicolumn{1}{l|}{$\begin{array}{l}\text { Required } \\
\text { EU }\end{array}$} & \multicolumn{1}{l|}{$\begin{array}{l}\text { Required } \\
\text { IASB }\end{array}$} \\
\hline Constant & -57.506 & -46.116 & -53.746 & -40.542 \\
\hline Legal System & 1.203 & -0.821 & -0.560 & 3.164 \\
\hline Uncertainty Avoidance & 0.665 & 0.592 & 0.645 & 0.596 \\
\hline Professionalism v. Statutory & 1.040 & 1.015 & 1.094 & 0.903 \\
\hline Asia & 26.373 & 19.445 & 15.406 & 13.279 \\
\hline Level of Development & 0 & 0 & 0 & 0 \\
\hline
\end{tabular}

Minitab results linear discriminant analysis- four categories

Table 6 - Minitab Results Linear Discriminant Analysis- Three Categories 


\begin{tabular}{|c|c|c|c|}
\hline \multirow[b]{2}{*}{ Put into Group } & \multicolumn{3}{|c|}{ True Group } \\
\hline & $\begin{array}{l}\text { Locally } \\
\text { Adopted }\end{array}$ & Not Required & $\begin{array}{l}\text { Required } \\
\text { IASB }\end{array}$ \\
\hline Locally Adopted & 10 & 1 & 2 \\
\hline Not Required & 1 & 4 & 2 \\
\hline Required IASB & 2 & 2 & 21 \\
\hline Total $\mathrm{N}$ & 13 & 7 & 25 \\
\hline $\mathrm{N}$ correct & 10 & 4 & 21 \\
\hline Proportion & 0.769 & 0.571 & 0.840 \\
\hline $\begin{array}{l}\mathrm{N}=45 \\
0.778\end{array}$ & $\mathrm{~N}$ Correct $=35$ & \multicolumn{2}{|c|}{ Proportion Correct $=$} \\
\hline \multicolumn{4}{|c|}{ Squared Distance Between Groups } \\
\hline & $\begin{array}{l}\text { Locally } \\
\text { Adopted }\end{array}$ & Not Required & $\begin{array}{l}\text { Required } \\
\text { IASB }\end{array}$ \\
\hline Locally Adopted & 0 & 1.85173 & 5.13472 \\
\hline Not Required & 1.85173 & 0 & 3.62771 \\
\hline Required IASB & 5.13472 & 3.62771 & 0 \\
\hline \multicolumn{4}{|c|}{ Linear Discriminant Function for Groups } \\
\hline & $\begin{array}{l}\text { Locally } \\
\text { Adopted }\end{array}$ & Not Required & $\begin{array}{l}\text { Required } \\
\text { IASB }\end{array}$ \\
\hline Constant & -43.397 & -37.929 & -34.202 \\
\hline Legal System & 0.477 & -1.894 & 2.487 \\
\hline Uncertainty Avoidance & 0.548 & 0.488 & 0.514 \\
\hline Professionalism v Statutory & 0.856 & 0.876 & 0.760 \\
\hline Asia & 15.685 & 13.276 & 9.449 \\
\hline Level of Development & 0 & 0 & 0 \\
\hline
\end{tabular}

Minitab results linear discriminant analysis- three categories

Table 7 - Minitab Results Linear Discriminant Analysis- Two Categories

True Group

\begin{tabular}{|l|r|r|}
\hline Put into Group & \multicolumn{1}{|c|}{$\begin{array}{c}\text { Not } \\
\text { Required }\end{array}$} & \multicolumn{2}{|c|}{ Required } \\
\hline Not Required & 6 & 7 \\
\hline Required & 3 & 49 \\
\hline Total N & 9 & 56 \\
\hline N correct & 6 & 49 \\
\hline
\end{tabular}




\begin{tabular}{|c|c|c|}
\hline Proportion & 0.667 & 0.875 \\
\hline $\mathrm{N}$ Correct $=55$ & \multicolumn{2}{|c|}{ Proportion Correct $=0.846$} \\
\hline \multicolumn{3}{|l|}{ Squared Distance Between Groups } \\
\hline & Not Required & Required \\
\hline Not Required & 0 & 3.49585 \\
\hline Required & 3.49585 & 0 \\
\hline \multicolumn{3}{|c|}{ Linear Discriminant Function for Groups } \\
\hline & Not Required & Required \\
\hline Constant & -37.934 & -31.962 \\
\hline Professionalism v. Statutory & 0.441 & 0.379 \\
\hline Inflation & 0.570 & 0.123 \\
\hline Asia & 29.904 & 29.704 \\
\hline Taxation & 0.830 & 0.712 \\
\hline Legal System & -8.465 & -4.756 \\
\hline
\end{tabular}

Minitab results linear discriminant analysis- two categories

In all three models the Asian region emerged are a significant variable. In the four and three category models the Asian region variable contributed more to the model than any other variable. These results are consistent with my ANOVA analysis and show that IFRS diffusion is happening within the Asian region. I find this quite fascinating, especially taking into account IASB's claim that IFRS is necessary because of globalization. These findings indicate that place is quite relevant, even in the midst of globalization.

In addition to the Asian region variable, level of professionalism and legal system were also found to contribute to all three classification models. The ANOVA analysis indicated that half of the countries in the permitted (not required) group have a common law form of governance which is supported by our discriminant analysis. This again would support Shima and Yang's (2012) argument that code law countries are less likely to adopt IFRS.

Professionalism $\mathrm{v}$ statutory control is one variable that was only found to be significant in the five category ANVOA analysis but was found to contribute to all three discriminant analysis. The numbers here are similar so it is difficult to tell exactly how much and in what ways this variable contributes to the model. One difference in the three models is that inflation and taxation were found to be significant in the two category analysis whereas uncertainty avoidance was found to be significant in the three and four category analysis. This is interesting because uncertainty avoidance was not found to be significant in any of our ANOVA tests. The means indicate higher uncertainty avoidance (85) for those countries that permit the use of IFRS (not require) and the low uncertainty avoidance (53) for those countries that do not permit the use of IFRS. Local adoption and required IASB have very 
similar means, 64 and 65 respectively. In both models uncertainty avoidance contributes most to the locally adopted category. Shima and Yang (2012) suggest that high uncertainty avoidance would deter IFRS adoption. The means suggest this is not the case but there is not enough evidence overall to say whether this prediction is supported.

Although inflation is not found to be significantly different in the ANOVA analysis the variable was found to contribute to the two category discriminant analysis. The inflation mean was higher in the not required category than the required category which seems to coincide with our model that shows a more powerful contribution in the not required category. This does seem to support Shima and Yang's (2012) suggestion that countries with high or hyper-inflationary economies are less likely to adopt IFRS although the overall support for inflation contributing to IFRS adoption is weak. Taxation was found to be significant in the four category ANOVA but not in the two category ANOVA and the opposite is true in the discriminant analysis. The not permitted category has the highest taxation mean which seems to support my hypothesis that countries heavily dependent on tax revenue are less likely to adopt IFRS.

Discriminant analysis does not tell us how each variable discriminates between groups, just the overall model contribution and the contribution between groups. Uncovering why uncertainty avoidance and inflation are significant in these models is an area for further research.

Overall, these discriminant analyses show that it is possible to create a model that is capable of classifying countries correctly using my expanded categories of adoption. This is important because it shows my newly developed typology allows for a more detailed analysis of why countries' choose the adoption method they chose. It can also help in future research in determining which adoption status would be most suitable for a particular country. Using this typology as a base a country may be able to determine which method could maximize a certain outcome variable, such as GDP growth or FDI as indicated by the outcomes literature.

\subsection{Logistic Regression}

Discriminant analysis assumes that each of the variables is normally distributed. Because several of the variables used in this study are not normally distributed I decided to confirm my discriminant analysis results with a multi-nominal logistic regression, which does not assume the variables to be normally distributed. The regression was run first using the four category classification and then again using the three category classification. Permitted countries were again treated as not required and level of development was again added as a control variable. The results of these regressions can be found in tables 8 and 9 and did confirm the discriminate analysis findings.

Table 8- Logistic Regression Table- Four Categories

\begin{tabular}{|lrrrrr|}
\hline Predictor & \multicolumn{1}{c}{ Coef } & $\underline{\text { SE Coef }}$ & $\underline{\mathbf{Z}}$ & $\underline{\text { P }}$ \\
Logit 1: (Required EU/Required IASB) & & & & & \\
Constant & -25.0944 & 8.82926 & -2.84 & 0.004 \\
Region7 & -10001.2 & 267261 & -0.04 & 0.97 \\
Professionalism V Statutory & 0.37816 & 0.125226 & 3.02 & 0.003 \\
\hline
\end{tabular}


Legal System

Uncertainty Avoidance

Level of Development

Logit 2: (Not Required/Required IASB)

Constant

Region7

Professionalism V Statutory

Legal System

Uncertainty Avoidance

Level of Development

Logit 3: (Locally Adopted/Required IASB)

Constant

Region7

Professionalism V Statutory

Legal System

Uncertainty Avoidance

Level of Development

Predictor

Logit 1: (Required EU/Required IASB)

Constant

Region7

Professionalism V Statutory

Legal System

Uncertainty Avoidance

Level of Development

Logit 2: (Not Required/Required IASB)

Constant

Region7

Professionalism V Statutory

Legal System

Uncertainty Avoidance

Level of Development

Logit 3: (Locally Adopted/Required IASB)

Constant

Region7

Professionalism V Statutory

Legal System

Uncertainty Avoidance

Level of Development
$-9.70076$

0.0957875

0.0000097

$-13.6262$

8.53125

0.260797

$-9.33723$

0.0133316

0.0000023

$-18.8051$

12.085

0.234378

$-7.62066$

0.0694976

0.0000344

Odds Ratio

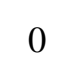

1.46

0

1.1

1

$5,070.8$

0

1.01

1

177,202
1.26
0
1.07
1

0
7.73147

3.98079

0.119659

3.74629

0.0467851

0.0000387

8.23134

4.2303

0.127437

3.85865

0.0456811

0.0000438

$95 \%$

Lower

CI

\section{Upper}

$\begin{array}{ll}-2.28 & 0.022\end{array}$

$2.86 \quad 0.004$

$1.84 \quad 0.066$

$-1.97 \quad 0.048$

1.520 .128

$0.79 \quad 0.432$

\begin{tabular}{l|l}
-1.76 & 0.078 \\
\hline 2.14 & 0.032 \\
\hline
\end{tabular}

$2.18 \quad 0.029$

$-2.49 \quad 0.013$

$0.28 \quad 0.776$

$0.06 \quad 0.953$

0

1.14

1.87

0.07

1.22

1

1
1

$$
\begin{gathered}
2.07 \quad 12 \\
1.03
\end{gathered}
$$

403,008.43

1.64

0

0.14

0.92

1.11

1

10

44.43

0.98

76.81E+038

1.62

0.94

1.17

10 
Log-Likelihood $=-33.523$

Test that all slopes are zero: $\mathrm{G}=85.983$

$\mathrm{DF}=15 \quad \mathrm{P}$-Value $=0$

Goodness-of-Fit Tests

Method Chi-Square DF

$\mathrm{P}$

$\begin{array}{lll}\text { Pearson } & 115.314 & 162\end{array}$

0.998

Deviance $\quad 67.047 \quad 162$

1.000

Logistic regression table- four categories

Table 9- Logistic Regression Table- Three Categories

\begin{tabular}{|c|c|c|c|c|}
\hline Predictor & Coef & $\underline{\text { SE Coef }}$ & $\underline{\mathbf{Z}}$ & $\underline{\mathbf{P}}$ \\
\hline \multicolumn{5}{|c|}{ Logit 1: (Not Required/Required IASB) } \\
\hline Constant & -15.8303 & 8.64544 & -1.83 & 0.067 \\
\hline Region7 & 8.94862 & 4.36679 & 2.05 & 0.04 \\
\hline Professionalism V Statutory & 0.343598 & 0.157514 & 2.18 & 0.029 \\
\hline Legal System & -11.2938 & 4.84035 & -2.33 & 0.02 \\
\hline Uncertainty Avoidance & -0.00442 & 0.049095 & -0.09 & 0.928 \\
\hline Level of Development & $-1.6 \mathrm{E}-05$ & $3.68 \mathrm{E}-05$ & -0.44 & 0.658 \\
\hline \multicolumn{5}{|c|}{ Logit 2: (Locally Adopted/Required IASB) } \\
\hline Constant & -19.532 & 8.56467 & -2.28 & 0.023 \\
\hline Region7 & 11.5659 & 4.55228 & 2.54 & 0.011 \\
\hline Professionalism V Statutory & 0.270503 & 0.141641 & 1.91 & 0.056 \\
\hline Legal System & -8.25071 & 4.26905 & -1.93 & 0.053 \\
\hline Uncertainty Avoidance & 0.074911 & 0.044416 & 1.69 & 0.092 \\
\hline \multirow[t]{2}{*}{ Level of Development } & $3.43 \mathrm{E}-05$ & 0.000034 & 1.01 & 0.313 \\
\hline & \multicolumn{2}{|r|}{$95 \%$} & \multicolumn{2}{|l|}{$\mathrm{CI}$} \\
\hline Predictor & Odds Ratio & Lower & \multicolumn{2}{|l|}{ Upper } \\
\hline \multicolumn{5}{|c|}{ Logit 1: (Not Required/Required IASB) } \\
\hline \multicolumn{5}{|l|}{ Constant } \\
\hline Region7 & $7,697.27$ & 1.48 & \multicolumn{2}{|l|}{$40,119,251.5$} \\
\hline Professionalism V Statutory & 1.41 & 1.04 & 1.92 & \\
\hline Legal System & 0 & 0 & 0.16 & \\
\hline Uncertainty Avoidance & 1 & 0.9 & 1.1 & \\
\hline Level of Development & 1 & 1 & 1 & \\
\hline \multicolumn{5}{|c|}{ Logit 2: (Locally Adopted/Required IASB) } \\
\hline \multicolumn{5}{|l|}{ Constant } \\
\hline Region7 & 105439.3 & 14.06 & 7.9.05E+12 & \\
\hline Professionalism V Statutory & 1.31 & 0.99 & 1.73 & \\
\hline
\end{tabular}




\begin{tabular}{|lccc} 
Legal System & 0 & 0 & 1.12 \\
Uncertainty Avoidance & 1.08 & 0.99 & 1.18 \\
Level of Development & 1 & 1 & 1 \\
& & & \\
Log-Likelihood $=-22.541$ & & & \\
Test that all slopes are zero: $\mathrm{G}=42.642$ & $\mathrm{DF}=10$, & P-Value $=0$
\end{tabular}

\begin{tabular}{lccc|} 
& \multicolumn{3}{c}{ Goodness-of-Fit Tests } \\
Method & Chi-Square & DF & P \\
Pearson & 70.0167 & 78 & 0.729 \\
Deviance & 45.0819 & 78 & 0.999 \\
\hline
\end{tabular}

Logistic regression table- three categories

As tables 8 and 9 show, the goodness of fit tests confirms that my models are appropriate to predict adoption status. Logistic regression requires the selection of a reference group which is suggested to be the category with the largest sample size, in this case required IASB. The analysis is then conducted by comparing each other category to the reference category. Additionally, Cramer (2006) argues logit regression is quite robust with respect to deviations of the disturbance distribution from the model therefore a robustness check is not necessary.

The four category logistic regression confirms the discriminant analysis results indicating a significant relationship between adoption status and level of professionalism, legal system, the Asian region and uncertainty avoidance. When comparing the EU to the reference category, level of professionalism falls into the rejection region of .05 . The coefficient tell us that for each point increase in level of professionalism the country is .378 times more likely to fall into the required EU category than the required IASB category. When comparing the not required category to required IASB level of professionalism is also found to be significant indicating that for each point increase in professionalism a country is .2608 times more likely to have a not required adoption status. The three category analysis shows a country is .344 times more likely to not require IFRS for each point increase they have in professionalism and .27 times more likely to choose local adoption over required IASB for each point increase in professionalism although this is lightly out of the selected rejection region with a p-value of.056. This confirms the ANOVA results that indicated that the EU relies more heavily of professional control and the required IASB category relies more heavily on statutory control. This conflicts with Braun and Rodrigues (2008) argument that countries with high levels of statutory control would resist IFRS adoption.

Legal system was also found to be significant in both the four and three category analysis. Comparing the required EU category to the required IASB category shows a country is 9.70 times less likely to fall into the required EU for each point increase in legal system. Because legal system is a binary dummy variable I can state that when a country is common law it is less likely to fall into the required EU category. When comparing the not required category to the reference event a country is 9.34 times less likely to not require IFRS when they are a common law country. Similar results were found in the three category analysis indicating a country is 11.29 times less likely to not require IFRS compared to 
require as issued by the IASB when they are a common law country. The locally adopted countries are 8.25 times less likely to have a common law form of governance although this was slightly out of the rejection range with a p-value of 0.053 . These legal system results again confirm our ANOVA analysis which indicated that the required IASB groups mean was significantly different from the required EU and not permitted groups. In addition, these results support Shima and Yang's (2012) argument that code law countries are less likely to adopt IFRS.

The uncertainty avoidance p-values were slightly outside my rejection range with the lowest p-values of 0.060 for the four category analysis and 0.092 for the three category analysis. Because they were only slightly outside of the rejection area and the results are confirmed by both ANOVA and the discriminant analysis and they contribute to my model I have left them in the model.

Uncertainty avoidance was found to be most significant when comparing the locally adopted category to required IASB in the three category analysis. For each point increase in uncertainty avoidance a country is .0749 times more likely to locally adopt IFRS. In the four category analysis uncertainty avoidance is most significant when comparing the required EU category to the required IASB category indicating that each point increase in uncertainty avoidance would increase the likelihood by .0958 times that a country would require EU over IASB. Although uncertainty avoidance was not found to be significant in the ANOVA it was significant in the discriminant analysis and it contributes to the model overall. Shima and Yang (2012) suggest that countries with higher uncertainty avoidance are less likely to adopt IFRS due to the perceived increased transparency. This seems to be the case when comparing local adoption with full IFRS adoption but not necessarily non-adopters.

The Asian region was found to be significant in all logits in both models with the exception of logit 1 in the four category analysis (comparing required EU to required IASB). When comparing the countries that do not require the use of IFRS to the countries that require IFRS as issued by the IASB the four category models indicates a country is 8.53 times more likely to not require the use of IFRS if it is located in the Asian region. Similar results are found in the three category analysis where a country is 8.95 times more likely to not require IFRS if it is located in the Asian region. When comparing countries that locally adopt to those that require IFRS as issued by the IASB the four category model indicates a country is 12.085 times more likely to locally adopt than require IFRS and the three category model indicates a country is 11.567 times more likely to locally adopt if it is located in the Asian region. This, again, confirms my ANOVA and linear discriminant results that shows countries in this Asian region are most likely to locally adopt IFRS. These findings are significant because region has not previously been researched as a possible driver of IFRS adoption status. These findings suggest that place is still very much a factor in IFRS implementation because countries from the same geographic region are often selecting not only whether or not to adopt IFRS but also whether or not to locally adopt IFRS.

In both models the locally adopted/ required IASB logit included the least amount of significant variables, only legal system and the Asian region for the four category analysis and only the Asian region for the three category analysis. This is one reason I decided to run a separate discriminant analysis and binary logistic regression on just the local adoption and 
required IFRS categories in an effort to uncover what factors were significant to the decision of locally adopt IFRS. The EU was treated as one case in the locally adopted category. Tables 10 and 11 summarize the results.

Table 10 Discriminant Analysis - Locally Adopted and Required IASB only

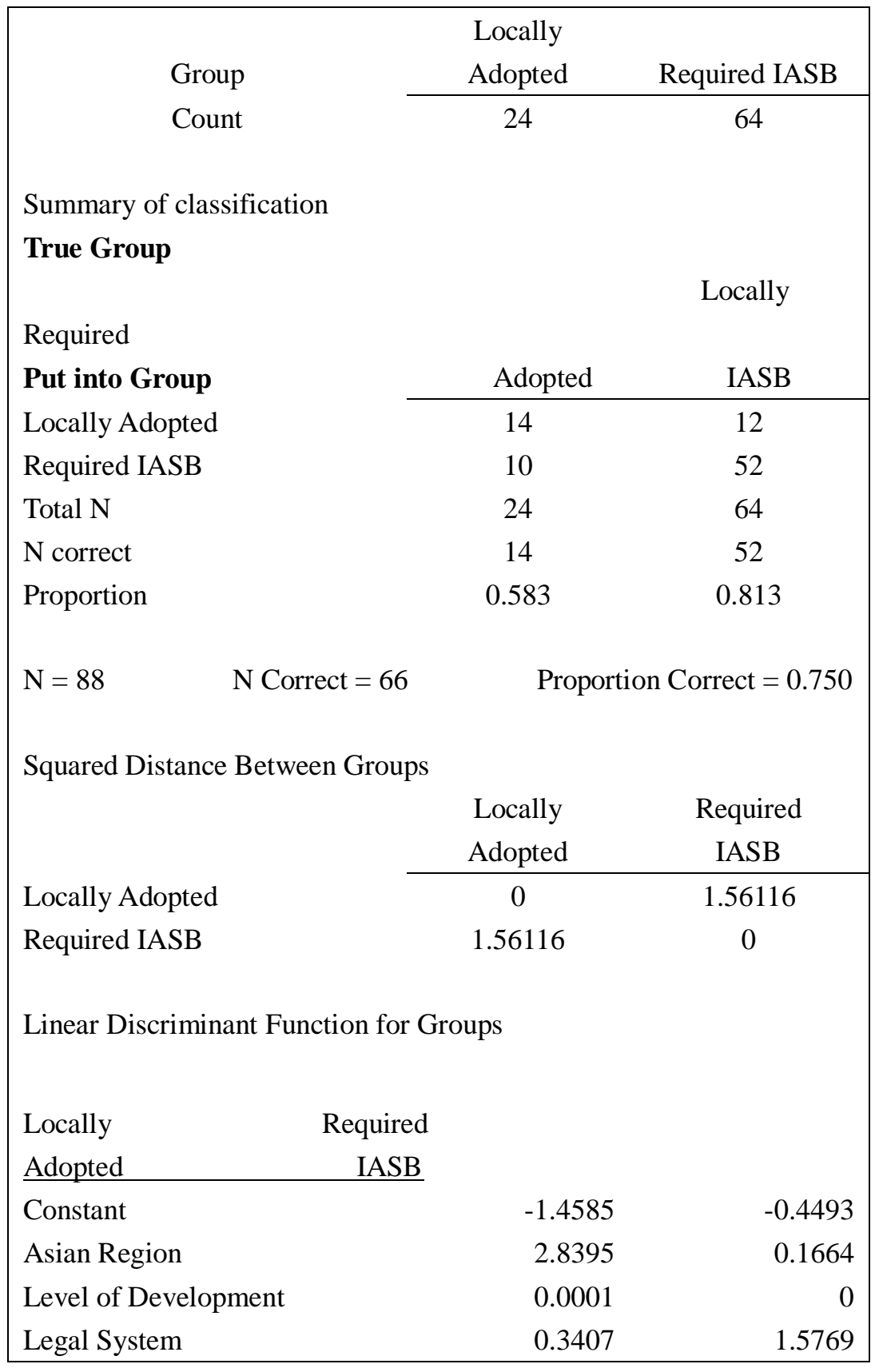

Discriminant Analysis - Locally Adopted and Required IASBonly 
Table 11 Binary Logistic Regression - Locally Adopted and Required IASB only

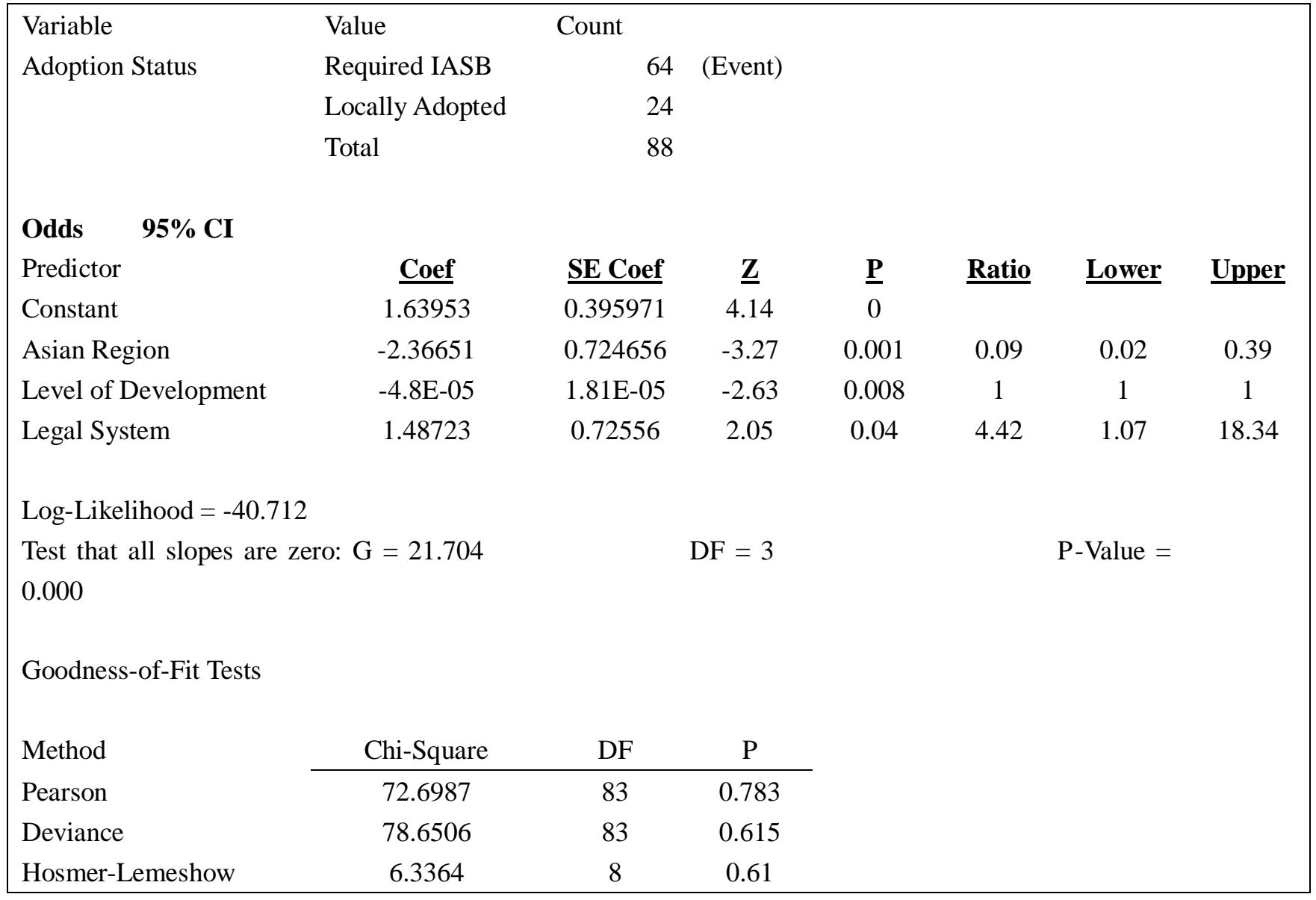

Binary logistic regression - Locally Adopted and Required IASB only

Both the discriminant analysis and binary logistic regression indicate that the Asian region variable, level of development and legal system are the most significant variables when discriminating between the locally adopted and required IASB categories. The discriminant analysis properly classified $75 \%$ of the countries using only these three variables. Level of professionalism and uncertainty avoidance are not significant in this model yet level of development is.

With the exception of hypothesis 1 , all of my hypotheses are at least partially supported by this study. The results are summarized in table 12 .

\section{Conclusion}

Although IFRS has clearly emerged as the preferred global accounting standard, previous studies of IFRS have mainly focused on post-adoption outcomes. The few existing IFRS adoption focused studies are either limited in scope or are based on outdated versions of IFRS. This paper fills these holes in the literature by offering a comprehensive analysis of IFRS 
adoption that shows that despite rapidly increasing globalization, geography is still important.

Existing models are inadequate in predicting adoption status when a more complex classification system is used. The differences shown between the binary analysis and my

Table 12- Results

\begin{tabular}{|c|c|c|c|}
\hline & \multicolumn{3}{|c|}{ Supported? } \\
\hline Hypothesis & ANOVA & $\begin{array}{c}\text { Linear } \\
\text { Discriminant } \\
\text { Analysis }\end{array}$ & $\begin{array}{l}\text { Multinomial } \\
\text { Logistic } \\
\text { Regression }\end{array}$ \\
\hline \multicolumn{4}{|c|}{ H1: Countries' major sources of finance impact IFRS adoption. } \\
\hline $\begin{array}{l}\text { H1a: Countries seeking external financing } \\
\text { through FDI or aid are more likely to adopt } \\
\text { IFRS. }\end{array}$ & EU effect & No & No \\
\hline $\begin{array}{l}\text { H1b: Countries that seek financing through } \\
\text { equity are less likely to adopt IFRS. }\end{array}$ & No & No & No \\
\hline \multicolumn{4}{|c|}{ H2: Countries' legal and taxation systems impact IFRS adoption. } \\
\hline $\begin{array}{c}\text { H2a: Code law countries are less likely to } \\
\text { adopt IFRS. }\end{array}$ & Yes & Yes & Yes \\
\hline $\begin{array}{l}\mathrm{H} 2 \mathrm{~b} \text { : Countries more heavily dependent on } \\
\text { tax revenue are less likely to adopt IFRS. }\end{array}$ & Yes & $\begin{array}{l}\text { Yes- two category } \\
\text { analysis }\end{array}$ & No \\
\hline \multicolumn{4}{|c|}{ H3: Countries' rate of inflation and level of development impacts IFRS adoption. } \\
\hline $\begin{array}{c}\text { H3a: Countries with high inflation are less } \\
\text { likely to adopt IFRS. }\end{array}$ & EU effect & $\begin{array}{l}\text { Yes- two category } \\
\text { analysis }\end{array}$ & No \\
\hline $\begin{array}{c}\mathrm{H} 3 \mathrm{~b} \text { : Countries that are less developed are } \\
\text { less likely to adopt IFRS. }\end{array}$ & Yes & Yes & Yes \\
\hline \multicolumn{4}{|c|}{ H4: Countries' education and culture impacts IFRS adoption. } \\
\hline $\begin{array}{l}\text { H4a: Countries with higher levels of } \\
\text { education are more likely to adopt IFRS. }\end{array}$ & No & No & No \\
\hline $\begin{array}{l}\text { H4b: Countries with high uncertainty } \\
\text { avoidance are less likely to adopt IFRS. }\end{array}$ & EU effect & Yes & Yes \\
\hline $\begin{array}{l}\text { H4c: Countries that have a higher level } \\
\text { statutory control are less likely to adopt } \\
\text { IFRS. }\end{array}$ & EU effect & Yes & Yes \\
\hline $\begin{array}{l}\text { H4d: Countries that have higher uniformity } \\
\text { are less likely to adopt IFRS. }\end{array}$ & EU effect & $\begin{array}{l}\text { Excluded due to } \\
\text { correlation }\end{array}$ & $\begin{array}{l}\text { Excluded due to } \\
\text { correlation }\end{array}$ \\
\hline $\begin{array}{l}\text { H4e: Countries that have higher } \\
\text { conservatism are less likely to adopt IFRS. }\end{array}$ & EU effect & $\begin{array}{l}\text { Excluded due to } \\
\text { correlation }\end{array}$ & $\begin{array}{l}\text { Excluded due to } \\
\text { correlation }\end{array}$ \\
\hline $\begin{array}{c}\text { H4f: Countries that have higher secrecy are } \\
\text { less likely to adopt IFRS. }\end{array}$ & EU effect & $\begin{array}{l}\text { Excluded due to } \\
\text { correlation }\end{array}$ & $\begin{array}{l}\text { Excluded due to } \\
\text { correlation }\end{array}$ \\
\hline
\end{tabular}


$\mathrm{H} 4 \mathrm{~g}$ : Countries that are more long-term oriented are less likely to adopt IFRS.

Summary of Results

expanded category analysis indicate that some of the variables proven to be good predictors in the binary classification model are not adequate to predict adoption status in a more complex classification system. The binary classification model is missing key significant variables and includes others that are not useful, creating a less efficient model. This expanded classification model can be used to create a more efficient model of economic growth post-IFRS adoption. This can assist in extending Larson's (1993) study that found African countries that locally adopted IAS to meet local environmental factors experienced higher economic growth than both the countries that fully adopted IAS or did not adopt IAS at all.

Although region variables have not been included in previous IFRS studies, place, specially the Asian region, was found to be a significant driver in choosing an adoption method in nearly all of my models. Future research is needed to better understand the high concentration of local adoption in this region. The results of this study can help standard setting bodies gain a better understanding of what types of variables are common among countries with the same adoption status. The evidence in this paper indicates that within each category; not required, local adoption and full adoption, common characteristic exists that differentiates the groups from each other.

Generally, countries that have a code law system of governance, are heavily dependent on tax revenue, have high levels of uncertainty avoidance and statutory control and are less developed are less likely to adopt IFRS. The IASB and other standard setting bodies can use this information to target these countries that have not yet adopted IFRS. Many of these countries may simply lack the resources to implement and enforce IFRS. A better understanding of what factors are common among non-adopters may help standard-setters understand barriers to IFRS adoption and possible adoption motivators. Future research is needed to determine why these characteristics make a country less likely to adopt IFRS as issued by the IASB. 


\section{References}

Adhikari, A., and R. Tondkar, (1992). Environmental Factors Influencing Accounting Disclosure Requirements of Global Stock Exchanges, Journal of International Financial Management and Accounting 4 (2): 75-105.

Allison, Paul D, Convergence Failures in Logistic Regression. SAS Global Forum 2008.

Alnajjar, F., (1986), Standardization in Accounting Practice: A Comparative International Study, International Journal of Accounting (Spring): 161-176.

Amable, Bruno. Diversity of Modern Capitalism. Oxford, GBR: Oxford University Press, UK, 2003. ProQuest ebrary. Web. 2 May 2015.

Ball, R., S. Kothari, and A. Robin, (2000), The Effects of International Institutional Factors on Properties of Accounting Earnings,Journal of Accounting and Economics 29: 1-51.

Belkaoui, A., (1995) Accounting Information Adequacy and Macroeconomic Determinants of Economic Growth: Cross-country Evidence. Advances in International Accounting 8: 87-97.

Braun, G. P., \& Rodriguez Jr., R. P. (2008). Earnings Management and Accounting Values: A Test of Gray (1988). Journal Of International Accounting Research, 7(2), 1-23.

Brown, P. (2011). International Financial Reporting Standards: what are the benefits?.Accounting and business research, 41(3), 269-285.

Choi, F. \& G. Meek. (2008). International Accounting, $6^{\text {th }}$ ed. Upper Saddle River, NJ; Pearson Education Inc.

Chua, W. F., \& Taylor, S. L. (2008). The rise and rise of IFRS: An examination of IFRS diffusion. Journal of Accounting and Public Policy, 27(6), 462-473.

Cooke, T., and R. Wallace, 1990, "Financial Disclosure Regulation and Its Environment: A Review and Further Analysis," Journal of Accounting and Public Policy 9: 79-110.

Craig, R., and J. Diga, 1996, "Financial Reporting Regulation in ASEAN: Features and Prospects," The International Journal of Accounting 31 (2): 239-259.

Cramer, J.S. Robustness of Logit Analysis: Unobserved Heterogeneity and Misspecified Disturbances. Discussion Paper: 2006/2007, UVA Econometrics.

Daske, H., Hail, L., Leuz, C. and Verdi, R. (2008), Mandatory IFRS Reporting around the World: Early Evidence on the Economic Consequences. Journal of Accounting Research, 46: 1085-1142.

DiMaggio, Paul J. and Walter W. Powell. (1983). The Iron Cage Revisited: Institutional Isomorphism and Collective Rationality in Organizational Fields. American Sociological Review, 48(2):147-160.

Doupnik, T., and S. Salter, 1993, "An Empirical Test of a Judgmental International Classification of Financial Reporting Practices," Journal of International Business Studies 24 (1): 41-60.

Doupnik, T., and S. Salter, 1995, "External Environment, Culture, and Accounting Practice: A Preliminary Test of a General Model of International Accounting Development," The International Journal of Accounting 30: 189-207.

Geiger, Marshall, \& Van Der Laan Smith, Joyce. (2010). The Effect of Institutional and Cultural Factors on the Perceptions of Earnings Management. Journal of International Accounting Research, 9(2), 21-43.

Gray, S. J.( 1988). Towards a theory of cultural influence on the development of accounting systems internationally.Abacus 24 _1_: 1-15.

Hardy, Melissa A. (1993) Regression with Dummy Variables. Sage Publications.

Hellman, Niclas. (2011). Soft Adoption and Reporting Incentives: A Study of the Impact of IFRS on Financial Statements in Sweden. Journal of International Accounting Research, 10(1), 61-83.

www.ifrs.com Retrieved 1/15/2015. AICPA.

www.iasb.org. Retrieved 1/15/2015. IFRS Foundation. 
Jaggi, B., and P. Low. (2000). Impact of Culture, Market Forces, and Legal System on Financial Disclosures. The International Journal of Accounting 35 (4): 495-519.

Larson, R. K. (1993). International Accounting Standards and Economic Growth: An Emperical Investigation of their Relationship in Africa. Research in the Third World Accounting. 2:27-43.

Larson, R. K., \& Kenny, S. (1995). An Empirical Analysis of International Accounting Standards, Equity Markets, and Economic Growth in Developing Countries. Journal Of International Financial Management \& Accounting, 6(2), 130-157.

Lasmin. (2011). Accounting standards internationalization revisit: Managing responsible diffusion. Procedia Social and Behavioral Sciences 25:363 -374.

Lasmin, L. (2012). The Unwanted Effects of International Financial Reporting Standards (IFRS) Adoption on International Trade and Investments in Developing Countries. Journal of Economics and Economic Education Research, Forthcoming.

Lewis, W. (1996). 'Directors' tips too generous for investors'.Financial Times, 6 August, p. 6.

Mande, Bashir. (2014). Emerging Nations and Financial Reporting Complex: A case for IFRS adoption in Nigeria. Journal of Finance, Accounting and Management. 5(2), 1-23.

Neumayer, Eric and Richard Perkins. (2005). Uneven Geographies of Organizational Practice: Explaining the Cross-National Transfer and Diffusion of ISO 9000. Economic Geography. 81 (3): 237-259.

Nobes, C., (2011), International Variations in IFRS Adoption and Practice. Certified Accountants Educational Trust for the Association of Chartered Certified Accountants. London.

Nobes, C., (1998), Towards a General Model of the Reasons for International Differences in Financial Reporting. ABACUS 34 (2): 162-187.

Pohar, Maja, Mateja Blas and Sandra Turk, (2004). Comparison of Logistic Regression and Linear Discriminant Analysis. Metodoloskizvezki. 1 (1), 143-161.

Ramanna, K., \&Sletten E. (2014). Network Effects in Countries' Adoption of IFRS. The Accounting Review. 89 (4): 1517-1543.

Rogerson, Peter, A. Statistical Methods for Geography: A Student's Guide, Third Edition. Los Angeles, Sage Publications Inc. 2010.

Roussey, R.S. (1992). Developing International Accounting and Auditing Standards for World Markets. Journal of International Accounting, Auditing and Taxation, 1(1),1-11.

Salter, S., 1998, "Corporate Financial Disclosure in Emerging Markets: Does Economic Development Matter?" The International Journal of Accounting 33 (2): 211-234.

Salter, S., and F. Niswander, 1995, "Cultural Influence on the Development of Accounting Systems Internationally: A test of Gray's [1988] Theory," Journal of International Business 26 (2): 379-397.

Saudagaran, S., and J. Diga, 2000, "The Institutional Environment of Financial Reporting Regulation in ASEAN," The International Journal of Accounting 35 (1): 1-26

Shima, K. M., \& Yang, D. C. (2012). Factors affecting the adoption of IFRS. International Journal of Business, 17(3), 276

Tarca, Ann. The Case for Global Accounting Standards: Arguments and Evidence. Professor of Accounting, University of Western Australia. Academic Fellow - Research, IFRS Foundation.

Vittinghoff, Eric and Charles E. McCulloch. (2007). Relaxing the Rule of Ten Events per Variable in Logistic and Cox Regression. Am. J. Epidemiol. (2007) 165 (6): 710-718.

Wyatt, Arthur R., and Joseph F. Yospe. "Wake-up call to American business: international accounting standards are on the way." Journal of Accountancy July 1993: 80+. Academic OneFile. Web. 6 Jan. 2014. 
Xiao, J., P. Weetman, and M. Sun, 2004, "Political Influence and Coexistence of a Uniform Accounting System and Accounting Standards: Recent development in China," ABACUS 40 (2): 193-218.

Zaidi, Syed Kashif Raza. (2012). IFRS Adoption and Enforcement as Antecedents of Economic Growth. The University at Texas, Department of Accounting.

Zeghal, D. and K. Mhedhbi.(2006). An Analysis of the Factors Affecting the Adoption of International Accounting Standards by Developing Countries. The International Journal of Accounting. 41; 373-386. 
Appendix 1- Kruskal-Wallis Results

\begin{tabular}{|c|c|c|c|c|}
\hline & & P-value & & \\
\hline $\begin{array}{c}\text { Independent } \\
\text { Variable }\end{array}$ & $\begin{array}{c}\text { Two } \\
\text { Categories }\end{array}$ & $\begin{array}{c}\text { Five } \\
\text { Categories }\end{array}$ & $\begin{array}{c}\text { Four } \\
\text { Categories }\end{array}$ & $\begin{array}{c}\text { Design or } \\
\text { Default }\end{array}$ \\
\hline Development & - & 0.000 & 0.171 & 0.024 \\
\hline Professionalism & - & 0.009 & - & 0.017 \\
\hline Uniformity & - & 0.009 & - & 0.017 \\
\hline Conservatism & - & - & - & 0.008 \\
\hline Secrecy & - & 0.014 & - & 0.006 \\
\hline Long Term & - & 0.012 & - & \\
\hline Legal System & - & - & - & 0.002 \\
\hline Aid & - & - & - & 0.148 \\
\hline VOC & - & - & - & 0.003 \\
\hline Region- Overall & - & - & - & 0.039 \\
\hline Region 2 & - & 0.000 & 0.025 & - \\
\hline Region 3 & 0.010 & 0.000 & 0.000 & - \\
\hline Region 5 & - & 0.000 & 0.004 & - \\
\hline Region 6 & 0.020 & 0.016 & 0.050 & - \\
\hline Region 7 & - & 0.000 & 0.012 & 0.018 \\
\hline
\end{tabular}




\section{MInstitute ${ }^{\text {Macrothink }}$}

International Journal of Accounting and Financial Reporting

ISSN 2162-3082

2015, Vol. 5, No. 2

\begin{tabular}{|c|c|c|c|c|c|c|c|}
\hline \multicolumn{2}{|c|}{ Table 4-Five Categories } & \multirow[b]{2}{*}{$\frac{\text { Permitted }}{\underline{\text { IASB }}}$} & \multirow{2}{*}{\begin{tabular}{l|} 
Means \\
$\underline{\text { Locally }}$ \\
Adopted \\
\end{tabular}} & \multirow[b]{2}{*}{$\frac{\text { Required }}{\underline{\underline{\mathrm{EU}}}}$} & \multirow[b]{2}{*}{$\underline{\underline{\text { Require }}}$} & \multirow[b]{2}{*}{$\begin{array}{l}\text { FisherPainrise- difference between } \\
\text { groups }\end{array}$} & \multirow[b]{2}{*}{ Details } \\
\hline & $\stackrel{\text { Not }}{\text { Permitted }}$ & & & & & & \\
\hline Legal System & 0.11 & 0.5 & 0.40 & 0.19 & 0.44 & $\begin{array}{l}\text { Permitted and Required IASB are different } \\
\text { from Required BU and Not Permittad }\end{array}$ & $\begin{array}{l}\text { Pernitted and Required IASB have higher means than Required } \\
\text { EU and Not Permitted indicaing counties that permit the use of } \\
\text { IFRS or require the use of IFRS as issued by the IASB are nore } \\
\text { likely to have a common law form of governance. }\end{array}$ \\
\hline $\begin{array}{l}\text { Level of } \\
\text { Development }\end{array}$ & 5639 & 17473 & 14005 & 32206 & 8098 & $\begin{array}{l}\text { Required by the EU is different from locally } \\
\text { adopted, not permitted and required IASB. }\end{array}$ & $\begin{array}{l}\text { Required EU has a significantly higher level of developinent than } \\
\text { the not permitted goup, the localy adopted group and the } \\
\text { required by IASB group. }\end{array}$ \\
\hline Taxation & 28.97 & 17.5 & 23.15 & 21.92 & 25.32 & $\begin{array}{l}\text { Permitted IASB is different from notpermitind } \\
\text { and required IASB. Also notpermitted is } \\
\text { different from locally adopted and required } \\
\text { EU. }\end{array}$ & $\begin{array}{l}\text { Permitted IASB has a significantly lower highest tax rate than not } \\
\text { permitted and required by LASB. Not permitted has a significatly } \\
\text { higher tax rate than locally adop ted or required EU. }\end{array}$ \\
\hline Extemal Debt, Log & 8.93 & 5.43 & 6.64 & 1.37 & 6.81 & $\begin{array}{l}\text { Required } \mathrm{EU} \text { is different from required IASB, } \\
\text { not permitted, permitted and locally adopted. } \\
\text { Also not permitted is different than permitted }\end{array}$ & $\begin{array}{l}\text { Extemal debt is significantly lower in EU than any other goup. } \\
\text { Not permitted has a significantly higher debt than perritted. }\end{array}$ \\
\hline Aid, Log & 7.70 & 5.27 & 5.56 & 0.30 & 6.60 & $\begin{array}{l}\text { Required by BU is different from locally } \\
\text { adopted, not permitted permitted andrequired } \\
\text { IASB. Also Not pernitted is different than } \\
\text { permitted. }\end{array}$ & $\begin{array}{l}\text { Foreign Aid is significanty lower for EU comries than any other } \\
\text { group. Not permitted has a significantly higher level of aid than } \\
\text { pernitted. }\end{array}$ \\
\hline $\begin{array}{l}\text { Professional r. } \\
\text { Statutory }\end{array}$ & 53.43 & 62.5 & 53.27 & 64.89 & 46.22 & Required $\mathrm{EU}$ is different from required IASB. & $\begin{array}{l}\text { Required BU relies more hesvily on professional control and } \\
\text { required by IASB relies more hesvily on statutory control }\end{array}$ \\
\hline $\begin{array}{l}\text { Uniform r. } \\
\text { Fleribility }\end{array}$ & 57.29 & 48.0 & 57.27 & 45.74 & 64.52 & Required $\mathrm{EU}$ is different from required IASB. & $\begin{array}{l}\text { Required EU accounting policies are more flesible compared to } \\
\text { sevpured IASB, which are nore uniform. }\end{array}$ \\
\hline $\begin{array}{l}\text { Secrecy r. } \\
\text { Transparency }\end{array}$ & 54.57 & 46.0 & 55.09 & 48.05 & 61.59 & Required $\mathrm{BU}$ is different from required IASB. & $\begin{array}{l}\text { Required EU accounting policies are nore transparent than } \\
\text { required IASB, which are more secretive. }\end{array}$ \\
\hline $\begin{array}{l}\text { Long Term r. Short } \\
\text { Term }\end{array}$ & 34.11 & 36.3 & 51.33 & 55.4 & 39.17 & $\begin{array}{l}\text { Required EU is different from both required } \\
\text { IASB and not permitted }\end{array}$ & $\begin{array}{l}\text { Required EU focus is more long term than both permitted and } \\
\text { required IASB, which are more focused on the shortterm. }\end{array}$ \\
\hline $\begin{array}{l}\text { South and Central } \\
\text { America and the } \\
\text { Caribbean }\end{array}$ & 0.111 & 0.438 & 0.100 & 0.000 & 0.333 & $\begin{array}{l}\text { Permitted IASB and Required IASB are } \\
\text { different than Required EU, locally adoptad } \\
\text { and permitted. }\end{array}$ & $\begin{array}{l}\text { Region } 2 \text { is comprised of South and Central America and the } \\
\text { Caribbean. Permitted IASB and Required IASB are nore likely to } \\
\text { be the adoption choire in tis region. }\end{array}$ \\
\hline Europe & 0.000 & 0.188 & 0.1500 & 1.000 & 0.0145 & $\begin{array}{l}\text { Required EU is different from all other groups } \\
\text { Also Permitted IASB and locally adopted ase } \\
\text { different from required IASB and not } \\
\text { permitted. }\end{array}$ & $\begin{array}{l}\text { Clealy EU required comtries are more lively to be in tis region } \\
\text { as it is the European region. But also the permitted IASB and } \\
\text { locally adopted are higher than required IASB and not perrittad } \\
\text { suggesting the nest mostpopular option for adoption is permitted } \\
\text { IASB and local adoption in Europe. }\end{array}$ \\
\hline Africa & .500 & 0.1250 & 0.050 & 0.0000 & 0.232 & $\begin{array}{l}\text { Not permitted is different from allother } \\
\text { groups. Required IASB is different from } \\
\text { required BU and locally adopted }\end{array}$ & $\begin{array}{l}\text { Region } 5 \text { is the African region. Not pernitted is the most lively } \\
\text { adoption choice withregured IASB being the nest highest. Local } \\
\text { adoption andrequired EU are the leastlikely options. }\end{array}$ \\
\hline MiddleEast & 0.0556 & 0.0000 & 0.0000 & 0.0000 & 0.1594 & $\begin{array}{l}\text { Required IASB is different from Required BU, } \\
\text { permitted and locally adopted. }\end{array}$ & $\begin{array}{l}\text { Region } 6 \text { is the Middle East Required IASB is the nostlikely } \\
\text { adoption choice in this region Required EU, permitted and local } \\
\text { adoption are the lasst likely. }\end{array}$ \\
\hline Asia & 0.222 & 0.188 & 0.550 & 0.000 & 0.1159 & $\begin{array}{l}\text { Locally adopted is different from allother } \\
\text { groups. Not permitted is also different from } \\
\text { Required } \mathrm{EU} \text {. }\end{array}$ & $\begin{array}{l}\text { Region } 7 \text { is the Asian region. This region has a high rate of local } \\
\text { adoption. Notpernited is the nest highest adoption choice with } \\
\text { Required EU being the least likely. }\end{array}$ \\
\hline
\end{tabular}

Fisher Pairwise summary 